\title{
PENGARUH MOTIVASI, KOMPETENSI, DISIPLIN DAN KOMPENSASI TERHADAP KINERJA KARYAWAN (STUDI KASUS PADA KARYAWAN PT. TEKTONINDO HENIDA JAYA GROUP)
}

\author{
Meita Pragiwani ${ }^{1}$, Elva Lestari $^{2}$, Mohammad Benny Alexandri $^{3}$ \\ meitasoetopo@gmail.com¹, elvalestari990@yahoo.com², mohammad.benny@unpad.ac.id ${ }^{3}$ \\ ${ }^{1,2}$ Sekolah Tinggi Ekonomi Indonesia, \\ ${ }^{3}$ Universitas Padjadjaran
}

\begin{abstract}
ABSTRAK
Penelitian ini bertujuan untuk mengetahui bagaimana pengaruh Motivasi, Kompetensi, Disiplin dan Kompensasi terhadap Kinerja Karyawan PT. Tektonindo Henida Jaya Group. Metode penelitian ini adalah metode kuantitatif dengan menggunakan data primer dan data sekunder. Jumlah sampel dalam penelitian ini adalah sebanyak 128 orang. Pengolahan data dalam penelitian ini menggunakan alat analisis SPSS, dan di analisis menggunakan analisis regresi linear berganda. Analisis yang digunakan dalam penelitian ini meliputi uji validitas, uji reliabilitas, koefisien determinasi, regresi linear berganda, dan uji t. Hasil penelitian menunjukkan bahwa, (1) motivasi tidak berpengaruh signifikan terhadap Kinerja karyawan, (2) kompetensi berpengaruh signifikan terhadap kinerja karyawan, (3) disiplin berpengaruh signifikan terhadap kinerja karyawan, (4) Kompensasi berpengaruh signifikan terhadap kinerja karyawan.
\end{abstract}

Kata Kunci : Motivasi, Kompensasi, Disiplin, Kompensasi dan Kinerja Karyawan

\section{PENDAHULUAN}

Dalam suatu perusahaan, salah satu faktor yang harus diperhatikan dan tidak boleh diabaikan oleh perusahaan adalah sumber daya manusia. Sumber daya manusia dalam hal ini sebagai kekuatan utama untuk bisa menjadikan suatu organisasi menjadi lebih berkembang. Oleh karena itu, setiap organisasi atau perusahaan dituntut untuk senantiasa memperhatikan aspek tersebut. Sumber daya perusahaan seperti modal dan asset mesin tidak memberikan hasil yang optimal apabila tidak didukung sumber daya manusia yang dikelola oleh perusahaan harus mampu menunjang kinerja yang baik sehingga perusahaan dapat mencapai tujuan, visi, dan misi perusahaan. Kinerja yang lebih tinggi mengandung arti terjadinya peningkatan efisiensi, efektivitas, atau kualitas yang lebih tinggi dari penyelesaian serangkaian tugas yang dibebankan kepada seorang karyawan dalam suatu organisasi atau perusahaan.

Sumber daya manusia dalam perusahaan dapat berarti orang-orang yang ada didalam perusahaan yang dapat pula mempengaruhi kualitas dan kuantitas perusahaan seperti karyawan, berkaitan dengan hal tersebut maka perusahaan dituntut agar mampu meningkatkan kinerja karyawannya. Salah satu cara untuk meningkatkan kinerja karyawan adalah dengan memenuhi kebutuhan-kebutuhan para pegawainya agar terwujud keseimbangan dalam perusahaan dan tidak ada kesenjangan antara tuntutan perusahaan dan kebutuhan pegawai. 


\section{Pengaruh Motivasi, Kompetensi, Disiplin Dan Kompensasi Terhadap Kinerja Karyawan \\ (Studi Kasus Pada Karyawan PT. Tektonindo Henida Jaya Group)}

(Meita Pragiwani, Elva Lestari, Mohammad Benny Alexandri)

PT. Tektonindo Henida Jaya Group yang beralamat di Komplek Royal Sunter Blok E No. 5, Jakarta Utara, DKI Jakarta merupakan salah satu perusahaan yang bergerak di bidang konstruksi darat dan supplier spare part kapal. Perusahaan konstruksi sekaligus supplier spare part kapal yang sudah berpengalaman selama 22 tahun memiliki memiliki 70 karyawan pada tahun 2018, setelah itu perusahaain ini memperluas sector usaha konstruksi untuk laut seperti pendalaman atau perluasan alur laut pelayaran, reklamasi dan pemasangan tiang pancang, dan sudah memiliki 4 armada kapal dengan masing-masing jenis berbeda. Secara otomatis jumlah karyawan pun terus meningkat menjadi 105 karyawan tetap dan 23 karyawan dalam masa percobaan per Desember 2019.

Kinerja karyawan merupakan salah satu faktor yang penting karena kemajuan organisasi atau perusahaan tergantung dari sumber daya manusia yang dimiliki. Jika kinerja meningkat maka keberhasilan mencapai tujuan perusahaan semakin terbuka lebar, tetapi apabila kinerja menurun maka bisa mengakibatkan kemunduran bagi perusahaan dan perusahaan tidak dapat mempertahankan usahanya (Jufrizen, 2018). Kinerja karyawan ada kalanya mengalami peningkatan dan kalanya mengalami penurunan, bahkan penurunan tersebut dapat mencapai titik yag dapat mengakibatkan perusahaan akan kehilangan pamornya di mata masyarakat. Hal ini perlu diperhatikan dan dipelajari bersama apa yang harus dilakukan untuk mengantisipasi hal tersebut.

Upaya yang dapat dilakukan adalah pemberian motivasi, dalam hal ini pimpinan berperan sebagai pemberi motivasi kepada para karyawan, dan ini menjadi sebuah kewajiban yang harus dilakukan oleh setiap pimpinan ataupun manajer dalam perusahaan. Para karyawan harus mampu menangkap berbagai dorongan yang diberikan oleh perusahaan yang bertujuan untuk dapat memacu motivasi kerja mereka dan meningkatkan kemampuan mereka dalam bekerja. Sejalan dengan yang dijelaskan oleh Astarina (2018) bahwa motivasi adalah suatu faktor yang mendorong seseorang untuk melaksanakan suatu aktivitas tertentu.

Berdasarkan hasil pengamatan peneliti PT. Tektonindo Henida Jaya dalam memotivasi karyawannya ditunjang dengan adanya upah karyawan sesuai UMK (Upah Maksimum Kota) dan adanya upah lembur serta dengan memperhatikan keadaan karyawannya. Apabila terjadi kecelakaan dalam bekerja karyawan mendapat tunjangan kesehatan berobat di poliklinik perusahaan dan mendapat asuransi Jamsostek. Motivasi penting karena motivasi adalah hal yang menyebabkan, menyalurkan, dan mendukung perilaku manusia supaya mau bekerja giat dan antusias mencapai hasil yang optimal.

Selain Motivasi, Kompetensi dan disiplin kerja faktor lainnya adalah pemberian kompensasi. Kompensasi merupakan sesuatu yang diterima pegawai sebagai pengganti kontribusi jasa mereka pada perusahaan. Setiap pegawai dalam suatu perusahaan mempunyai keinginan untuk mendapatkan kompensasi yang sesuai dengan harapan mereka. Kompensasi adalah semua pendapatan yang berbentuk uang, barang langsung atau tidak langsung yang diterima pegawai sebagai imbalan jasa yang diberikan pada perusahaan (Jufrizen, 2017). Pemberian kompensasi merupakan salah satu pelaksanaan fungsi MSDM yang berhubungan dengan semua jenis pemberian penghargaan individual sebagai pertukaran dalam melakukan tugas keorganisasian. Bila kompensasi diberikan secara benar, para pegawai akan lebih terpuaskan dan 
termotivasi untuk mencapai tujuan perusahaan. Kompensasi penting bagi pegawai sebagai individu, karena besarnya kompensasi mencerminkan ukuran nilai kerja pegawai tersebut. Oleh karena itu, bila pegawai memandang kompensasinya tidak memadai maka kinerja, motivasi dan kepuasaan kerja pegawai akan turun (Suratman Hadi, 2019). Fenomena terkait kompensasi pegawai dimana pembayaran tunjangan kinerja dan uang makan pegawai yang sering terlambat, kecilnya insentif lembur pegawai serta kurangnya beberapa fasilitas pendukung pekerjaan seperti kurangnya perangkat telepon (hanya terdapat 1 pesawat telepon/faksimili) untuk 58 pegawai, fasilitas wifi yang sering lambat bahkan mati, kurangnya laptop atau komputer sehingga pegawai harus menggunakan laptop pribadi, mesin fotokopi yang sudah usang (sering mengakibatkan kertas menyangkut pada mesin fotokopi dan dokumen asli sobek.

1. Apakah Motivasi berpengaruh terhadap kinerja karyawan pada PT. Tektonindo Henida Jaya Grup?

2. Apakah Kompetensi berpengaruh terhadap kinerja karyawan pada PT. Tektonindo Henida Jaya Grup?

3. Apakah Disiplin berpengaruh terhadap kinerja karyawan pada PT. Tektonindo Henida Jaya Grup?

4. Apakah Kompensasi berpengaruh terhadap kinerja pada PT. Tektonindo Henida Jaya Grup?

\section{TINJAUAN PUSTAKA}

\section{Motivasi}

\section{Pengertian Motivasi}

Kebutuhan yang dimiliki oleh setiap karyawan berbeda-beda, sehingga motivasi yang diperlukan atau yang dibutuhkan pun berbeda satu sama lainnya. Untuk mencapai sasaran-sasaran dari pekerjaan yang telah ditentukan sebelumnya diperlukan motivasi yang tinggi bagi setiap karyawan. Di bawah ini akan dijelaskan pengertian motivasi menurut beberapa ahli, yaitu:

Fachreza et al., (2018) menyatakan bahwa motivasi adalah faktor-faktor yang sifatnya ekstrinsik bersumber dari luar diri yang turut menentukan perilaku seseorang dalam kehidupan seseorang. Motivasi kerja sebagai kesediaan untuk melaksanakan upaya tingkat tinggi untuk mencapai tujuan-tujuan keorganisasian yang dikondisikan oleh kemampuan upaya untuk memenuhi kebutuhan individual tertentu (Hanafi \& Yohana, 2017). Lusri \& Siagian (2017) menjelaskan bahwa motivasi (motivation) merupakan sebuah proses yang menjelaskan intensitas, arah, dan ketekunan seorang individu untuk mencapai tujuannya.

Dari beberapa penjelasan di atas, maka disimpulkan motivasi kerja adalah merupakan suatu bagian yang penting di dalam suatu perusahaan yang fungsinya sebagai alat untuk pencapaian tujuan yang telah ditetapkan dan ingin dicapai oleh perusahaan. Motivasi juga mengandung dua tujuan utama yaitu untuk diri pribadi karyawan dan untuk tujuan perusahaan tempat dimana bekerja.

\section{Kompetensi}

Kompetensi pegawai adalah suatu untuk melaksanakan pekerjaan atau tugas yang dilandasi atas keterampilan dan pengetahuan serta didukung oleh sikap kerja yang dituntut oleh pekerjaan tersebut. Keterampilan atau kemampuan yang diperlukan pegawai yang ditunjukkan oleh kemampuan dengan konsisten memberikan tingkat kinerja yang memadai atau tinggi dalam suatu fungsi pekerjaan. 


\section{Pengaruh Motivasi, Kompetensi, Disiplin Dan Kompensasi Terhadap Kinerja Karyawan \\ (Studi Kasus Pada Karyawan PT. Tektonindo Henida Jaya Group)}

(Meita Pragiwani, Elva Lestari, Mohammad Benny Alexandri)

Kompetensi adalah terminologi yang sering didengar dan diucapkan banyak orang. Kita pun sering mendengar atau bahkan mengucapkan terminologi itu dalam berbagai penggunaan, khususnya terkait dengan pengembangan sumber daya manusia. Ada yang menginterpretasikan kompetensi sepadan dengan kemampuan atau kecakapan, ada lagi yang mengartikan sepadan dengan keterampilan, pengetahuan dan berpendidikan tinggi. Untuk lebih jelasnya akan dipaparkan beberapa pengertian tentang kompetensi (Priansa, 2017).

Kompetensi merupakan karakteristik yang mendasari seseorang berkaitan dengan efektivitas kinerja individu dalam pekerjaannya atau karakteristik dasar individu yang memiliki hubungan kausal atau sebagai sebab akibat dengan kriteria yang dijadikan acuan. Kompetensi terletak pada bagian dalam setiap manusia dan selamanya ada pada kepribadian seseorang yang dapat memprediksikan tingkah laku dan performansi secara luas pada semua situasi dan tugas pekerjaan (Triastuti, 2019).

\section{Pengetahuan}

\section{Pengertian Pengetahuan}

Pengetahuan adalah informasi yang dimiliki seseorang untuk bidang tertentu. Skor atau tes pengetahuan sering gagal untuk memprediksi kinerja SDM kerena skor tersebut tidak berhasil mengukur pengetahuan dan keahlian seperti apa yang seharusnya dilakukan dalam pekerjaan. Pengetahuan pegawai turut menentukan berhasil tidaknya pelaksanaan tugas yang dibebankan kepadanya, pengetahuan merujuk pada informasi dan hasil pembelajaran. Pegawai yang mempunyai pengetahuan yang cukup akan meningkatkan efisiensi perusahaan. Namun bagi pegawai yang belum mempunyai pengetahuan cukup, maka akan bekerja tersendat-sendat. Pemborosan bahan, waktu dan tenaga serta faktor produksi yang lain akan diperbuat oleh pegawai berpengetahuan kurang. Pemborosan ini akan mempertinggi biaya dalam pencapaian tujuan organisasi. Pengetahuan mencerminkan kemampuan kognitif seorang karyawan berupa kemampuan untuk mengenal, memahami, menyadari dan menghayati suatu tugas/pekerjaan. Karena itu, pengetahuan seseorang karyawan dapat dikembangkan melalui pendidikan, baik formal maupun non formal serta pengalaman. Pendidikan membekali seseorang dengan dasar-dasar pengetahuan, teori, logika, pengetahuan umum, kemampuan analisis serta pengembangan watak dan kepribadian (Mussardo, 2019).

\section{Pengertian Kemampuan}

Kemampuan adalah sebuah penilaian terkini atas apa yang dapat dilakukan seseorang. Menurut Abdulqadir (2016) kemampuan kerja merupakan suatu keadaan yang ada pada diri pekerja yang secara sungguhsungguh berdaya guna dan berhasil guna dalam bekerja sesuai bidang pekerjaannya. Kemampuan adalah sifat yang dibawa sejak lahir/dipelajari yang memungkinkan seseorang menyelesaikan tugasnya. Kemampuan menunjukkan potensi orang untuk melaksanakan tugas/pekerjaan. Kemampuan pegawai dalam melaksanakan tugasnya merupakan perwujudan dari pengetahuan dan keterampilan yang dimiliki. Tidak semua karyawan memiliki kemampuan untuk bekerja dengan baik meskipun sudah dimotivasi dengan baik (Wijaya \& Andreani, 2015).

Berdasarkan uraian diatas dapat disimpulkan bahwa yang dimaksud dengan kemampuan pegawai dalam penelitian ini adalah semua potensi yang dimiliki pegawai untuk 
melaksanakan tugas berdasarkan pengetahuan, sikap, pengalaman, dan pendidikan.

\section{Pentingnya Kemampuan}

Pentingnya kemampuan karena kemampuan adalah hal yang menyebabkan, menyalurkan, dan mendukung kinerja karyawan, supaya mau bekerja giat dan antusias mencapai hasil yang optimal. Kemampuan semakin penting karena manajer memberikan pekerjaan pada bawahannya untuk dikerjakan dengan baik dan terintegrasi kepada tujuan yang diinginkan. Perusahaan bukan saja mengharapkan karyawan mampu, cakap, dan terampil, tetapi yang terpenting mereka dapat bekerja dengan hasil yang maksimal. Motivasi dan kecakapan karyawan tidak ada artinya bagi perusahaan jika mereka tidak memiliki kemampuan dalam bekerja. Untuk memberikan kemampuan pada masingmasing karyawan, manajer harus mengetahui motif dan kemampuan yang diinginkan karyawan. Orang mau bekerja adalah untuk dapat memenuhi kebutuhan, baik kebutuhan yang disadari (conscious needs) maupun kebutuhan yang tidak disadari (uncocious needs), berbentuk materi atau nonmateri, baik kebutuhan jasmani maupun rohani (Hendra, 2020).

\section{Pengertian Disiplin}

Disiplin merupakan sesuatu yang lebih banyak berasal dari dalam diri sendiri. Disiplin akan diperlihatkan dalam bentuk mematuhi dan mengikuti peraturanperaturan dan kebijakan-kebijakan yang diberlakukan oleh perusahaan. Dengan disiplinnya para karyawan, maka prestasi kerja karyawan juga akan meningkat, yang berujung kepada pencapaian tujuan perusahaan. Oleh karena itu kedisiplinan memiliki pengaruh penting terhadap proses pencapaian tujuan perusahaan.
Disiplin adalah perilaku seseorang yang sesuai dengan peraturan, prosedur kerja yang ada atau disiplin adalah sikap, tingkah laku, dan perbuatan yang sesuai dengan peraturan dari organisasi baik tertulis maupun yang tidak tertulis. Disiplin yang baik mencerminkan besarnya tanggung jawab seseorang terhadap tugas-tugas yang diberikan kepadanya. Hal ini mendorong gairah kerja, semangat kerja, dan terwujudnya tujuan perusahaan. Melalui disiplin akan mencerminkan kekuatan, karena biasanya seseorang yang berhasil dalam karyanya adalah mereka yang memiliki disiplin tinggi (Ginting, 2018).

\section{Pengertian Kompensasi}

Bagi setiap karyawan yang bekerja pada perusahaan pastilah mengharapkan balas jasa atas apa yang telah diberikan dan dilakukan untuk perusahaan. Pada dasarnya gaji atau upah merupakan alasan utama bagi karyawan untuk bekerja, selanjutnya karyawan akan mengharapkan balas jasa yang lebih dari sekedar gaji atas apa yang dihasilkan untuk perusahaan, seperti bonus, insentif, dan tunjangan non financial seperti reward dan peluang promosi.

Berikut penjelasan pengertian kompensasi menurut beberapa ahli, di antaranya, Nursam (2017) yang mendefenisikan kompensasi sebagai sesuatu yang diterima karyawan atas jasa yang mereka berikan atau kontribusikan kepada pekerjaannya. Menurut Leonardo \& Andreani, (2015), kompensasi adalah segala sesuatu yang diterima oleh karyawan sebagai balas jasa atas kontribusinya kepada perusahaan atau organisasi. Menurut Dessler (2017), kompensasi karyawan (employee compensation) meliputi semua bentuk bayaran yang diberikan kepada karyawan dan timbul dari hubungan kerja mereka. 


\section{Kinerja Karyawan}

\section{Pengertian Kinerja}

Setiap perusahaan di dalam menjalankan seluruh kegiatan operasionalnya untuk mencapai tujuan yang telah ditetapkan oleh perusahaan tersebut. Yang terdiri dari elemen elemen sumber daya manusia (karyawan) yang mempunyai tugas serta tanggung jawab yang sudah diberikan dan harus dilaksanakan dengan tujuan optimalisasi dan efisiensi pencapaian tujuan yang akan dicapai, baik yang harus dilaksanakan secara sendiri-sendiri maupun secara berkelompok (tim). Kinerja perusahaan sangat dipengaruhi oleh kinerja para karyawannya, karena karyawan adalah penggerak utama untuk setiap kegiatan operasional perusahaan dan yang harus berperan aktif demi tercapainya tujuan perusahaan.

Berikut pengertian kinerja menurut para ahli diantaranya Nursam (2017) mendefenisikan kinerja adalah tingkat pencapaian hasil atas pelaksanaan tugas tertentu. Kinerja perusahaan adalah tingkat pencapaian hasil dalam rangka mewujudkan tujuan perusahaan. Manajemen kinerja adalah keseluruhan kegiatan yang dilakukan untuk meningkatkan kinerja perusahaan atau organisasi, termasuk kinerja masing-masing individu dan kelompok kerja di perusahaan tersebut.

\section{Populasi}

Menurut Sugiyono (2016) populasi adalah wilayah generalisasi yang terdiri atas obyek/subyek yang mempunyai kualitas dan karakteristik tertentu yang ditetapkan oleh peneliti untuk dipelajari dan kemudian ditarik kesimpulannya.
Yang dijadikan sebagai populasi dalam penelitian ini adalah seluruh karyawan PT. Tektonindo Henida Jaya Grup yang berjumlah 128 orang karyawan.

\section{Sampel}

Sampel adalah bagian dari jumlah dan karakteristik yang dimiliki oleh populasi tersebut. Sampel tersebut sebagai perwakilan, harus mempunyai sifat-sifat atau ciri-ciri yang terdapat pada populasi (Sugiyono, 2016).

Dalam penelitian ini penulis menggunakan metode Nonprobabilty Sampling sedangkan cara pengambilan sampel yang digunakan adalah sampling jenuh. Menurut Sugiyono (2016) yang dimaksud Teknik probability sampling adalah Teknik pengambilan sampel yang tidak memberi peluang atau kesempatan sama bagi setiap unsur atau anggota populasi untuk menjadi sampel, sehingga disimpulkan sampel diambil dari jumlah populasi yaitu 128 orang.

\section{METODE PENELITIAN}

Pengolahan data dalam analisis ini menggunakan program software Statistical Product and Service Solution (SPSS) versi 23 untuk analisis data. Sedangkan penyajian datanya dengan menggunakan tabel dan statistik.

Untuk memenuhi persyaratan instrumen penelitian maka dilakukan uji validitas dan uji reliabilitas. Penelitian ini menggunakan analisis regresi linear berganda. Selanjutnya dilakukan uji hipotesis yang bertujuan untuk mengetahui tentang kekuatan variabel bebas terhadap variabel terikat. Uji hipotesis meliputi analisis regresi berganda, koefisien determinasi (R2), dan uji t. 


\section{PEMBAHASAN}

Berikut adalah hasil dari regresi linear berganda yang diregresikan dengan program spss versi 23 :

Tabel 4.15 Hasil Regresi Linear Berganda Coefficients

\begin{tabular}{|l|l|l|l|l|l|}
\hline \multirow{2}{*}{ Model } & \multicolumn{2}{|l|}{$\begin{array}{l}\text { Unstandardized } \\
\text { Coefficients }\end{array}$} & \multicolumn{2}{l|}{$\begin{array}{l}\text { Standardized } \\
\text { Coefficients }\end{array}$} & \\
\cline { 2 - 5 } & $\mathrm{B}$ & Std. Error & Beta & $\mathrm{t}$ & \multirow{2}{*}{ Sig. } \\
\hline 1 (Constant) & 4.177 & 1.826 & & 2.287 & .024 \\
MOTIVASI & -.171 & .093 & -.181 & -1.847 & .067 \\
KOMPETENSI & .205 & .066 & .252 & 3.088 & .002 \\
DISIPLIN & .359 & .081 & .362 & 4.403 & .000 \\
KOMPENSASI & .475 & .102 & .448 & 4.674 & .000 \\
\hline
\end{tabular}

a. Dependent Variable: VAR00005

Berdasarkan tabel diatas, dapat diketahui bahwa nilai konstanta regresi sebesar 4,177, koefisien regresi variabel Motivasi $\left(\mathrm{X}_{1}\right)$ sebesar -0,171, variabel Kompetensi $\left(\mathrm{X}_{2}\right)$ sebesar 0,205, variabel Disiplin (X3) sebesar 0,359 dan variable kompensasi 0,475. Dari hasil ini dapatlah dibuat persamaan regresi yaitu sebagai berikut:

PERFi $=\alpha i+\beta 1$. Motivasi $+\beta 2$. Kompetensi $+\beta 3$.Disiplin $+\beta 4$.Kompensasi

$\mathrm{PERFi}=4,177+$-0,171.Motivasi + 0,205.Kompetensi + 0,359.Disp + 0,475.Kompensasi

Dari persamaan diatas dapat dijelaskan bahwa :

1. Koefisien X1 sebesar -0,171. Nilai koefisien $\mathrm{X} 1$ bernilai negatif dan tidak memiliki pengaruh Signifikan.

2. Koefisien regresi kompetensi $\left(\mathrm{X}_{2}\right)$ terhadap kinerja karyawan (Y) sebesar 0,205. Nilai koefisien tersebut memberikan arti bahwa apabila nilai variabel kompetensi naik, maka nilai kinerja karyawan akan naik dengan asumsi variabel bebas yang lain dari model regresi adalah tetap.
3. Koefisien regresi disiplin (X3) terhadap kinerja karyawan (Y) sebesar 0,359. Nilai koefisien tersebut memberikan arti bahwa apabila nilai variabel disiplin naik, maka nilai kinerja karyawan akan naik dengan asumsi variabel bebas yang lain dari model regresi adalah tetap.

4. Koefisien regresi kompensasi (X4) terhadap kinerja karyawan (Y) sebesar 0,475. Nilai koefisien tersebut memberikan arti bahwa apabila nilai variabel kompensasi naik, maka nilai kinerja karyawan akan naik dengan asumsi variabel bebas yang lain dari model regresi adalah tetap.

\section{Analisis Koefisien Determinasi}

Koefisien determinasi berguna untuk mengukur seberapa jauh kemampuan model dalam menerangkan variasi variabel dependen (Y). Dibawah ini adalah tabel koefisien determinasi yang dihasilkan dalam penelitian dengan menggunakan program spss versi 23 : 
Tabel 4.16 Uji Koefisien Determinasi

\begin{tabular}{l}
\begin{tabular}{|l|l|l|l|l|}
\hline Model Summary \\
\hline 1 & R & R Square & $\begin{array}{l}\text { Adjusted } \\
\text { Square }\end{array}$ & $\begin{array}{l}\text { Std. Error of } \\
\text { the Estimate }\end{array}$ \\
\hline
\end{tabular} \\
\hline
\end{tabular}

a. Predictors: (Constant), X1, X2, X3, X4

Berdasarkan tabel diatas, dapat diketahui bahwa besarnya nilai adjusted $\mathrm{R}$ square adalah sebesar 0,625 atau $62,5 \%$. Ini mengartikan bahwa variasi dari kinerja karyawan dapat dijelaskan oleh variasi dari motivasi $\left(\mathrm{X}_{1}\right)$, kompetensi $\left(\mathrm{X}_{2}\right)$, disiplin $\left(\mathrm{X}_{3}\right)$ dan kompensasi (X4) adalah sebesar $62,5 \%$, sedangkan sisanya sebesar $37,5 \%$ dijelaskan oleh faktor lain, yang mana faktor tersebut tidak diteliti dalam penelitian ini.

\section{Analisis Uji t ( Uji parsial )}

Uji t digunakan untuk menguji signifikansi hubungan antara variabel $\mathrm{X}$ dan variabel $\mathrm{Y}$ Berikut adalah hasil uji t secara parsial : secara parsial atau dapat dikatakan uji t pada dasarnya menunjukan seberapa jauh satu variabel independen secara individual dalam menerangkan variasi-variasi dependen. Pengujian hipotesis ini akan dilakukan dengan menggunakan tingkat signifikansi sebesar $0,05 \quad(\alpha=5 \%)$ atau tingkat keyakinan sebesar 0,95\% (Ghozali, 2012). Dalam melakukan uji $t$ digunakan penyusunan hipotesis nol (H0) dan hipotesis alternatif (Ha). (Ghozali, 2012).

Tabel 4.17 Hasil Uji t

Coefficients $^{\mathrm{a}}$

\begin{tabular}{|l|l|l|l|l|l|}
\hline \multirow{2}{*}{ Model } & \multicolumn{2}{|l|}{$\begin{array}{l}\text { Unstandardized } \\
\text { Coefficients }\end{array}$} & $\begin{array}{l}\text { Standardized } \\
\text { Coefficients }\end{array}$ & & \\
\cline { 2 - 4 } & $\mathrm{B}$ & Std. Error & Beta & $\mathrm{t}$ & Sig. \\
\hline 1 (Constant) & 4.177 & 1.826 & & 2.287 & .024 \\
& & .093 & -.181 & -1.847 & .067 \\
_MOTIVASI & -.171 & .093 & .252 & 3.088 & .002 \\
_KOMPETENSI & .205 & .066 & .362 & 4.403 & .000 \\
_DISIPLIN & .359 & .081 & .448 & 4.674 & .000 \\
__KOMPENSASI & .475 & .102 & & &
\end{tabular}

a. Dependent Variable: VAR00005

Uji t menunjukkan bahwa seberapa jauh pengaruh variabel independen secara individual dalam menenrangkan variasivariasi variabel dependen. Derajat signifikansi yang digunakan dalam penelitian ini adalah $5 \%$ atau 0,05 .

\section{Pengaruh Motivasi Terhadap Kinerja Karyawan}

Dari hasil analisis regresi linier berganda menunjukkan bahwa motivasi tidak berpengaruh signifikan terhadap 
kinerja karyawan. Artinya bahwa motivasi yang diterima oleh karyawan tidak berpengaruh terhadap kinerja karyawan tersebut. Hal ini mengindikasikan bahwa kebutuhan untuk diakui, melakukan kebutuhan yang terbaik dan kebutuhan kemandirian tidak mempengaruhi kinerja karyawan di PT. Tektonindo Henida Jaya.

Hasil penelitian ini mendukung hasil penelitian sebelumnya yang dilakukan oleh Dapu (2015). Yang menghasilkan bahwa Motivasi tidak berpengaruh terhadap Kinerja Karyawan. dengan sampel sebanyak 60 orang responden dengan menggunakan kuesioner dan analisis regresi linear berganda.

Dalam PT. Tektonindo Henida Jaya para team leader, kordinator divisi sudah memberikan motivasi kepada para karyawan agar para karyawan dapat meningkatkan kreativitas, dan nilai mutu pekerjaanya, akan tetapi hal itu tidak cukup untuk mendorong mereka, karena pada dasarnya karyawan hanya bekerja sesuai dengan apa yang diperintahkan oleh atasan. Kebanyakan karyawan bekerja hanya memikirkan target untuk mendapatkan bonus di luar gaji, dan setelah mereka mencapai target, kebanyakan dari mereka sudah merasa puas sampai disitu saja, dan mereka menyelesaikan pekerjaan agar tidak kehilangan pekerjaan.

\section{Pengaruh kompetensi Terhadap Kinerja Karyawan}

Dari hasil analisis regresi linier berganda menunjukkan bahwa kompetensi berpengaruh terhadap kinerja karyawan. Penelitian ini mendukung hasil penelitian sebelumnya yang dilakukan oleh Wahyuningsih dan Maelani (2018). Teknik sampling yang digunakan dalam penelitian ini adalah menggunakan random sampling berjumlah 84 responden. Teknik pengujian data yang digunakan meliputi uji validitas dengan analisis factor, uji reliabilitas dengan alpha Cronbach, analisis regresi berganda, dan uji signifikan koefisien determinasi untuk membuktikan kebenaran hipotesis. Hasil penelitian membuktikan bahwa Kompetensi berpengaruh positif dan signifikan terhadap kinerja karyawan.

Pada PT. Tektonindo Henida Jaya, pengalaman kerja yang dimiliki, kecakapan dalam mengusai pekerjaan dan kemamapuan intelektual dan fisik menjadi variable yang meningkatkan kinerja karywan sehingga tujuan perusahaan dapat dicapai dengan baik dan cepat.

\section{Pengaruh Disiplin Terhadap Kinerja Karyawan}

Dari hasil analisis regresi linier berganda menunjukkan bahwa disiplin yang dimiliki oleh karyawan berpengaruh signifikan terhadap kinerja karyawan. Hal ini berarti bahwa dengan tingkat kedisiplinan yang tinggi dapat membuat karyawan dalam melaksanakan tugas-tugas atau pekerjaannya dengan teratur, tertib dan lancar, sehingga hasil kerja yang dicapai (kinerja) akan meningkat dan pastinya akan berdampak kepada hasil yang diperoleh perusahaan. Hasil ini sama dengan penelitian sebelumnya yang dilakukan oleh Margaretha, Perizade, Widiyanti, dan Zunaidah (2020) pada PT. Semen Baturaja sebanyak 547 responden. Hasil penelitian menunjukkan bahwa disiplin kerja berpengaruh positif dan signifikan terhadap kinerja karyawan pada PT Semen Baturaja (Persero), Tbk.

Hasil penelitian inipun memperkuat teori yang dikemukakan oleh Hasibuan (2016), bahwa kedisiplinan merupakan fungsi operatif MSDM yang terpenting, karena semakin baik disiplin karyawan, semakin tinggi kinerja karyawan tersebut. 


\section{Pengaruh Motivasi, Kompetensi, Disiplin Dan Kompensasi Terhadap Kinerja Karyawan}

(Studi Kasus Pada Karyawan PT. Tektonindo Henida Jaya Group)

(Meita Pragiwani, Elva Lestari, Mohammad Benny Alexandri)

PT. Tektonindo Henida Jaya memang sangat mementingkan kedisiplinan, bagi perusahaan kedisiplinan karyawan menjadi dasar penilaian dan berdasarkan gabungan dari seluruh general competency.

\section{Pengaruh kompensasi Terhadap Kinerja Karyawan}

Dari hasil analisis regresi linier berganda menunjukkan bahwa kompensasi berpengaruh signifikan terhadap kinerja karyawan. Artinya bahwa kompensasi yang diterima oleh karyawan berpengaruh terhadap kinerja karyawan tersebut. Hal ini mengindikasikan bahwa dengan adanya pemberian kompensasi yang diberikan perusahaan kepada karyawan seperti gaji, insentif, bonus, tunjangan asuransi, tunjangan cuti, peluang promosi, dan aman pada jabatan dapat meningkatkan kinerja karyawan di PT. Tektonindo Henida Jaya.

Hasil penelitian ini mendukung hasil penelitian sebelumnya yang dilakukan oleh Alwi (2017) yang menghasilkan bahwa kompensasi berpengaruh signifikan terhadap kinerja karyawan, dengan sampel sebanyak 75 orang responden dengan menggunakan metode analisis regresi linear berganda dengan bantuan program SPPS 17. Kemudian hasil pengujian tersebut juga mendukung hasil penelitian Muliati (2014) dengan sampel sebanyak 115 responden, yang menghasilkan bahwa kompensasi berpengaruh signifikan terhadap kinerja pegawai, dengan metode analisis regresi linear berganda.

PT. Tektonindo Henida Jaya tidak pernah memberikan kompensasi melewati batas waktu yang sudah disepakati. Perusahaan juga terbuka dalam perhitungan jumlah bonus dan insentif yang rumus perhitungannya bisa diakses oleh seluruh

karyawan. Team HRD juga tidak pernah lupa dan lalai dengan pemberian tunjangan hari raya, tunjangan kesehatan seperti mendaftarkan nama karyawan untuk mendapatkan BPJS, pemberian insentif dan bonus selalu sesuai perhitungan berdasarkan target yang dicapai karyawan, dan kenaikan gaji setiap tahun sesuai dengan kesepakatan.

\section{SIMPULAN}

Berdasarkan analisis data dan pembahasan mengenai pengaruh motivasi, kompetensi, disiplin, dan kompensasi terhadap kinerja karyawan, yang mana analisis data tersebut diperoleh dari sebanyak 128 orang karyawan PT. Tektonindo Henida Jaya Group yang telah dijelaskan pada bab sebelumnya, maka penulis dapat menarik kesimpulan sebagai berikut :

1. Motivasi tidak berpengaruh signifikan terhadap kinerja karyawan. Maka dapat disimpulkan bahwa H0 diterima dan $\mathrm{Ha}$ ditolak. Hal ini menunjukkan bahwa Motivasi kerja yang dimiliki oleh karyawan tidak berpengaruh terhadap kinerja karyawan tersebut. Para karyawan hanya bekerja sesuai dengan apa yang diperintahkan oleh atasan saja dan karena takut akan kehilangan pekerjaan, tanpa ingin berusaha mengembangkan potensi yang ada dalam diri dan mengaktualisasikan diri untuk lebih berkembang dan berpengalaman di dunia kerja.

2. Kompetensi berpengaruh terhadap kinerja karyawan. Maka dapat disimpulkan bahwa HO ditolak dan Ha ditolak. Hal ini menunjukkan bahwa Kompetensi yang dimiliki oleh karyawan berpengaruh terhadap kinerja karyawan tersebut. Pengalaman, kecakapan dalam menguasai pekerjaan dan 
kemampuan intelektual dan fisik yang dimiliki karyawan PT. Tektonindo Henida jaya menjadi variable yang meningkatkan kinerja karyawan sehingga tujuan perusahaan dapat dicapai dengan baik dan cepat

3. Disiplin berpengaruh signifikan terhadap kinerja karyawan. Maka dapat disimpulkan bahwa HO ditolak dan Ha diterima. Hal ini menunjukkan bahwa tingkat kedisplinan yang dimiliki oleh karyawan akan mempengaruhi hasil kinerja karyawan tersebut. Semakin meningkat kedisiplinan karyawan, maka semakin menigkat pula kinerja para karyawan tersebut, begitu juga sebaliknya jika tingkat kedisiplinan karyawan menurun, maka kinerja para karyawan juga akan semakin menurun.

4. Kompensasi berpengaruh signifikan terhadap kinerja karyawan. Maka dapat disimpulkan bahwa H0 ditolak dan Ha diterima. Artinya bahwa kompensasi yang telah diberikan oleh perusahaan

\section{DAFTAR PUSTAKA}

Alwi, M. (2017). Pengaruh Kompensasi, Kompetensi, dan Motivasi terhadap Kinerja Karyawan Cv. Xyz. Jurnal Logika Universitas Swadaya Gunung Jati Vol 4, No 2. ISSN 2809-1876. https://doi.org/10.7210/lsgj.v8i3.6

Astarina, I. (2018). Pengaruh Motivasi Dan Kompensasi Terhadap Kinerja Karyawan Pada Pt. Alfa Scorpii Pematang Reba. Jurnal Manajemen dan Bisnis. Vol 7 No 4. e-ISSN 332- kepada karyawan dapat mempengaruhi hasil kinerja karyawan tersebut.

\section{SARAN}

Berdasarkan hasil penelitian dan simpulan, maka peneliti memberikan saran sebagai berikut :

1. Agar para leader dan manager perusahaan untuk lebih memotivasi lagi para karyawan dan mendorong semangat kerja karyawan untuk mau belajar lebih dan mengembangkan potensi yang ada pada diri para karyawan tersebut.

2 Agar karyawan dapat meningkatkan minat dan semangat kerja untuk memberikan kontribusi terbaik untuk perusahaan.

3. Agar karyawan dapat meningkatkan disiplin ketika diberikan tanggung jawab pekerjaan untuk menghasilkan kinerja yang bagus.

4. Mengenai dengan kompensasi sebaiknya perusahaan memberikan peluang promosi kepada karyawan yang mempunyai kinerja bagus sebagai bentuk achievement terhadap mereka.

5. Agar karyawan dapat meningkatkan kualitas kerja untuk pendapatkan hasil kerja yang maksimal.

4154. Has been accredited GARUDA at 2018 by Indonesia Ministry of Research, Technlogy and Higher Education (RistekDikti) Republic of Indonesia as an academic Journal.

Dessler, G. (2017). Manajemen Sumber Daya Manusia. In Pelatihan dan Pengembangan. Jakarta: Pearson.

Fachreza, Musnadi, S., \& Majid, M. S. A. (2018). Pengaruh Motivasi kerja, lingkungan kerja, dan budaya organisasi terhadap kinerja karyawan 
dan dampaknya pada kinerja Bank Aceh Syariah di Kota Banda Aceh. Jurnal Magister Manajemen. Vol 14 No 2. ISSN 5293145. Has been accredited GARUDA at 2018 by Indonesia Ministry of Research, Technlogy and Higher Education (RistekDikti) Republic of Indonesia as an academic Journal.

Ginting, N. B. (2018). Pengaruh Disiplin Kerja dan Komunikasi Terhadap Kinerja Karyawan di PT. Sekar Mulia Abadi Medan. AJIE - Asian Journal of Innovation and Entrepreneurship Vol 9 No 1. ISSN 18728383.

Hanafi, B. D., \& Yohana, C. (2017). Pengaruh Motivasi, dan Lingkungan Kerja, Terhadap Kinerja Karyawan, Dengan Kepuasan Kerja Sebagai Variabel Mediasi Pada PT Bni Lifeinsurance. Jurnal Pendidikan Ekonomi Dan Bisnis (JPEB) Vol 13 No $7 . \quad$ ISSN 1652-89. https://doi.org/10.21009/jpeb.005.1.6

Hendra, H. (2020). Pengaruh Budaya Organisasi, Pelatihan Dan Motivasi Terhadap Kinerja Karyawan Pada Universitas Tjut Nyak Dhien Medan. Maneggio: Jurnal Ilmiah Magister Manajemen. Vol 3 No 1. e-ISSN 2961727. Has been accredited GARUDA at 2020 by Indonesia Ministry of Research, Technlogy and Higher Education (RistekDikti) Republic of Indonesia as an academic Journal.

Herdiansyah, H. (2015). Wawancara, Observasi, dan Focus Groups sebagai Instrument Penggalian Data Kualitatif. In Metodologi Penelitian. Jawa Timur: Salemba.
Jufrizen, J. (2017). Efek Mediasi Kepuasan Kerja pada Pengaruh Kompensasi Terhadap Kinerja Karyawan. Jurnal IImiah Manajemen dan Bisnis. Vol 8 No 5. e-ISSN 15240-254. Has been accredited SINTA 3 at 2017 by Indonesia Ministry of Research, Technlogy and Higher Education (RistekDikti) Republic of Indonesia as an academic Journal.

Jufrizen, J. (2018). Peran Motivasi Kerja Dalam Memoderasi Pengaruh Kompensasi Dan Disiplin Kerja Terhadap Kinerja Karyawan. Prosiding: The National Conferences Management and Business (NCMAB) 109-119.

Lusri, L., \& Siagian, H. (2017). Pengaruh Motivasi Kerja Terhadap Kinerja Karyawan Melalui Kepuasan Kerja Sebagai Variabel Mediasi Pada Karyawan PT . Borwita Citra Prima Surabaya. ABA Journal. ISSN 2917029. DOI: 10.1002

Moeheriono. (2018). Pengukuran Kinerja Berbasis Kompetensi. ISBN 978979769449. Jakarta: Rajawali Pers

Mussardo, G. (2019). Pengetahuan. Statistical Field Theor. Jawa Tengah: Nugra Media

Nursam, N. (2017). Manajemen Kinerja. Kelola: Journal of Islamic Education Management. ISSN 2091-8819. doi :10.24256

Priansa, D. J. (2017). Manajemen Kinerja Kepegawaian dalam Pengelolaan SDM Perusahaan. In Cetakan ke-1. Jakarta: Alfabeta 
Sugiyono, P. D. (2016). Metode Penelitian Kuantitatif, Kualitatif, dan R\&D. Jakarta: Alfabeta

Suratman Hadi. (2019). Pengaruh Lingkungan Kerja Terhadap Kinerja Karyawan (Studi pada Karyawan Kantor Pelayanan Pajak Pratama Malang Utara). Parameter Vol 7 No 2. ISSN 419927-12. doi: 10.37751
Triastuti, D. A. (2019). Pengaruh Lingkungan Kerja, Kompetensi Dan Iklim Organisasi Terhadap Kinerja Pegawai. Journal of Management Review.

Wijaya, T., \& Andreani, F. (2015). Pengaruh Motivasi Dan Kompensasi Terhadap Kinerja Karyawan Pada PT Sinar Jaya Abadi Bersama. Agora. ISSN 218217. doi: 10.12901 